The transatlantic mobility of this book, initially published in Paris in 2017 under the title Sphère publique, intérêts privés: Enquête sur un grand brouillage (Presses de Sciences Po, Paris), and which now starts an anglophone life in Ithaca, could come as a surprise. As it engages in a thick description of France's field of power in the current neoliberal context, this opus was not necessarily an obvious candidate for translation to an American audience. It took many opportunities and a lot of enthusiasm for this transnational circulation to happen. It all started in Paris, in my little office under the roof of the old Sorbonne, when Pierre France, a $\mathrm{PhD}$ candidate in political science at the Université Paris 1-Sorbonne, agreed to help me conduct an in-depth exploration of the world, visions, and trajectories of French politicians and top-level bureaucrats who had moved en masse into the corporate bar over the past two decades. As our collaboration developed, Pierre played an instrumental role in the making of the book through continuous dialogic exchanges that proved critical in shaping its storyline. While he has mostly contributed to the writing of the second chapter, the whole book bears the trace of our many fruitful discussions.

But the transatlantic part of the book's journey only started later on. Camille Robcis, a member of the editorial board of the Corpus Juris: The Humanities in Law and Politics series, first envisioned a possible passage. Elizabeth Anker, the editor of this book series, took an immediate interest in welcoming the book. Her early and contagious conviction that it was telling a story of broader scope and significance helped me all the way through the editing process (as did a number of friendly dinners enjoyed in Paris over that period together with Stéphanie and Mitch). Yet the book also needed a connector to make less exotic the many French idiosyncracies that are unavoidable when it comes to discussing notions of the public and the state. Samuel Moyn was kind enough to accept the challenge. Given his scholarship at the crossroads of history, politics, and law; his strong engagement with the politics of neoliberalism; and his own long-standing relationship with France, I could not think of a better person for authoring the foreword to this book, which I am confident will enhance its relevance beyond audiences merely interested in the case of France. I wish to thank him here. As 
the journey moved to its more concrete steps, the financial and institutional support of Labex Tepsis, an international research platform in the social sciences of politics housed by the Ecole des hautes études en sciences sociales (EHESS), proved essential in making the translation possible. As for my previous books, Meg Morley agreed to do most of the translating work and I owe a special debt of gratitude to her. Yet the journey into the United States called for more than just a linguistic translation: it also needed some reformatting on a deeper level. I wish to thank Diane Berrett Brown, the managing editor of the series at Cornell University Press, and all the editorial team, who have been patient enough to help me through the many steps of the editing process.

There is finally one key element that has made this whole process possible, and it is time for me to confess it: I have my own "American in Paris," Stéphanie Hennette, whose long-standing and very special relationship with the United States has turned my own transatlantic move into a personal and loving journey, an adventure that has progressively extended to our sons Anatole and Basile. To them I gratefully dedicate this book. 


\section{THE NEOLIBERAL REPUBLIC}


